\title{
Molecular chaperone therapy- the future in cancer
}

\author{
Abdul Moid Shehzad*, Om Dawani, Shehryar Munir and Syed Anas Hussain
}

Molecular chaperone or heat shock proteins (HSP) are vital proteins that increase cell survival by allowing it to combat stress caused by injurious stimuli through certain cyto-protective mechanisms [1]. These cytoprotective mechanisms of molecular chaperones, especially HSP 90 [2], have a negative effect designated to favor tumor growth and metastasis among breast cancer, leukemia, pancreatic and ovarian cancer [3,4].

Stabilization of the structure of important agents in malignant transformation, such as kinases (Src and Met tyrosine kinases) and transcription factors (e.g., hypoxia inducible factor, HIF1) allows molecular chaperones to stimulate angiogenesis by promoting endothelial cell proliferation and permitting growth of cancer beyond the oxygen capacity of tissue diffusion [5]. Molecular chaperones disrupt the programmed cell death pathway (apoptosis) by inducing mutant forms of tumor growth suppressors and DNA repair proteins ( $\mathrm{p} 53$ and MSH2) [6-8]. New multi-target antineoplastic drugs like Geldanamycin, purine scaffold inhibitors, and Radicicol [9] have been developed to oppose all such activity of molecular chaperones.

The new therapeutic agents or Heat Shock Protein inhibitors function by blocking the intrinsic ATPase activity of molecular chaperones allowing oncogenic proteins (Raf-1, Akt/PKB, ErbB2, Cdk4, Polo-1, Met)[10] to be targeted by the ubiquitin proteasome pathway due to no chaperone protection $[2,9]$. An example is the positive result of the phase II clinical trial of HER2 positive breast cancer being treated by Hsp90 inhibitor 17AAG followed with Trastuzumab [11]. Although directed towards distinct molecular targets, HSF inhibitors also inhibit other multiple cancer promoting signaling pathways, increasing the efficacy in treatment [12]. Synergistically usage of these new molecular chaperone inhibitors with standard chemotherapeutic drugs had positive results of tumor cell apoptosis and significant

\footnotetext{
* Correspondence: moid.shehzad91@gmail.com

Medical Student, Dow Medical College, Dow University of Health Sciences, Karachi, Pakistan
}

regression in treatment of leukemia and breast cancer respectively [13],

Despite effective results in phase 1 of clinical trials [14], HSP inhibitors cause reduction in stress-adaptive responses of normal cells leading to apoptosis [1]. Depletion of $\mathrm{C} 2 \mathrm{C} 12$ (for muscle cell survival) by Geldanamycin derivatives [15] and colon adenocarcinoma growth during 17AAG treatment are some of the examples of this adverse effect [16]. However, greater affinity of HSP inhibitors towards tumoral chaperones specifically, is a reason that many clinical trials have not reported this side effect, for example 17AAG has 100 times greater affinity for tumoral versus normal cell HSP90 [1,17].

Although still in phase 2 of clinical trial, the development of HSP inhibitors provides an exciting alternative for molecular-based therapy in cancer [18]. HSP inhibitors like Gantespib, have shown a more promising future with a broader spectrum against various malignancies and better safety advantages in comparison to first and second generations HSP inhibitors [19]. Overall the advanced mechanism-based use of HSP inhibitors, both alone and in combination with other drugs, should help in the improvement of treatment of multiple forms of cancer in the future with minimal side effects.

Received: 6 April 2012 Accepted: 23 July 2012

Published: 13 August 2012

\section{References}

1. Almeida MB, Nascimento JL, Herculano AM, Crespo-López ME: Molecular chaperones: towards new therapeutic levels. Biomed Pharmacother 2011, 65(4):239-243.

2. Paul W: Auditing the Pharmacological Accounts for Hsp90 Molecular Chaperone Inhibitors: Unfolding the Relationship between Pharmacokinetics and Pharmacodynamics. Mol Cancer Ther February 2003, 2:131

3. Ciocca DR, Calderwood SK: Heat shock proteins in cancer: diagnostic, prognostic, predictive, and treatment implications. Cell Stress Chaperones 2005, 10(2):86-103.

4. Soti C, Csermely P: Molecular chaperones in the etiology and therapy of cancer. Pathol Oncol Res 1998, 4(4):316-21.

5. Pratt WB, Toft DO: Regulation of signaling protein function and trafficking by the hsp90/hsp70-based chaperone machinery. Exp Biol Med trafficking by the hsp90/hsp70-baywo
(Maywo 2003, 228(2):111-133. 
6. Calderwood SK, et al: Heat shock proteins in cancer: chaperones of tumorigenesis. Trends Biochem Sci 2006, 31(3):164-72.

7. Pratt WB, Toft DO: Regulation of signaling protein function and trafficking by the hsp90/hsp70-based chaperone machinery. Exp Biol Med (Maywood) 2003, 228(2):111-33.

8. Ekman S, et al: Hsp90 as a therapeutic target in patients with oesophageal carcinoma. Expert Opin Ther Targets 2010, 14(3):317-28.

9. Soti $\mathrm{C}$, et al: Heat shock proteins as emerging therapeutic targets. $\mathrm{Br} \mathrm{J}$ Pharmacol 2005, 146(6):769-80.

10. Neckers L: Hsp90 inhibitors as novel cancer chemotherapeutic agents. Trends Mol. Med. 2002, 8:55-61.

11. Stuart K: Calderwood, Jianlin Gong. Molecular chaperones in mammary cancer growth and breast tumor therapy 2012, 113(4):1096-1103.

12. Neckers L: Heat shock protein 90: the cancer chaperone. J Biosci 2007 , 32(3):517-30.

13. Soti $\mathrm{C}$, et al: Heat shock proteins as emerging therapeutic targets. $\mathrm{Br} J$ Pharmacol 2005, 146(6):769-80

14. Neckers L, IVy SP: Heat shock protein 90. Curr Opin Oncol. 2003, 15(6):419-24.

15. Yun BG, Matts RL: Differential effects of Hsp90 inhibition on protein kinases regulating signal transduction pathways required for myoblast differentiation. Exp Cell Res 2005, 307(1):212-23.

16. Vasilevskaya IA, Rakitina TV, O'Dwyer PJ: Geldanamycin and its 17allylamino- 17-demethoxy analogue antagonize the action of cisplatin in human colon adenocarcinoma cells: differential caspase activation as a basis for interaction. Cancer Res 2003, 63(12):3241-6.

17. Kamal $\mathrm{A}$, et al: A high-affinity conformation of $\mathrm{Hsp} 90$ confers tumour selectivity on Hsp90 inhibitors. Nature 2003, 425(6956):407-10.

18. Powers MV, Workman P: Targeting of multiple signalling pathways by heat shock protein 90 molecular chaperone inhibitors. Endocr Relat Cancer. 2006, 13(1):125-35.

19. Ying W, Du Z, Sun L, Foley KP, Proia DA, Blackman RK, Zhou D, Inoue T, Tatsuta N, Sang J, Ye S, Acquaviva J, Ogawa LS, Wada Y, Barsoum J, Koya K: Ganetespib, a Unique Triazolone-Containing Hsp90 Inhibitor, Exhibits Potent Antitumor Activity and a Superior Safety Profile for Cancer Therapy. Mol Cancer Ther 2012, 11(2):475-484.

doi:10.1186/1750-9378-7-20

Cite this article as: Shehzad et al:: Molecular chaperone therapy- the future in cancer. Infectious Agents and Cancer 2012 7:20.

\section{Submit your next manuscript to BioMed Central and take full advantage of:}

- Convenient online submission

- Thorough peer review

- No space constraints or color figure charges

- Immediate publication on acceptance

- Inclusion in PubMed, CAS, Scopus and Google Scholar

- Research which is freely available for redistribution 